\title{
EFFECTIVENESS OF PRESSURE-RELIEVING SHOES/INSOLES ON LOWERING THE PLANTAR PRESSURE OF DIABETIC FOOT: A META-ANALYSIS
}

\author{
Xinrong $\mathrm{ZHI}^{1}$, Weiping WANG ${ }^{2}$, Bo XU ${ }^{1}$, Jin $\mathrm{ZHOU}^{1 *}$ \\ ${ }^{1}$ National Engineering Laboratory for Clean Technology of Leather Manufacture, Sichuan University; Chengdu 610065, P. R. \\ China; 1436160237@qq.com, 228447319@qq.com,zj_scu@scu.edu.cn \\ ${ }^{2} 452$ Hospital of PLA; Chengdu 610065, P. R. China; wwp021006@sina.com
}

Received: 15.05.2020

Accepted: 28.08 .2020

https://doi.org/10.24264/Ifj.20.4.3

\begin{abstract}
EFFECTIVENESS OF PRESSURE-RELIEVING SHOES/INSOLES ON LOWERING THE PLANTAR PRESSURE OF DIABETIC FOOT: A META-ANALYSIS ABSTRACT. Since current reports demonstrated a higher prevalence of foot ulcers in diabetic patients who suffer from foot complication, the preventing occurrence of foot ulcers were the primary target in foot care. Clinical consensus introduced a variety of pressure-relieving products to diabetic patients and clinicians prescribed these products to their patients and recommended them used in daily life. However, available data were still controversial and whether these products could effectively reduce plantar pressure or not were uncertain. Thereby, this meta-analysis aimed first to summary all relevant findings in current database and secondly to explore whether pressure-relieving insoles/shoes can really relieve plantar pressure and what's differences between customized products (shoes/insoles) and standard ones in reducing plantar pressure. We first searched published articles cited from Web of Science, Medline via OVID, CINAHL, SCOPUS, INFORMIT, Cochrane Central and EMBASE via OVID. Then we filtered observational studies reporting experimental effect of pressure-relieving insoles/ shoes. Meanwhile, we set up primary outcome as overall mean peak plantar pressure (MPP) and secondary outcomes as MPP at various plantar regions and MPP at insoles/shoes with various structure designs. Our results show that pressure-relieving products (shoes/insoles) did lower the amplitude of pressure concentration; effect of custom-made and pre-fabricated products on pressure-relieving were similar. These findings suggested that no matter pressure-relieving products were custom-made or prefabricated standard one, if they were designed targeting to increase overall plantar contact areas, such as designed based on plantar model, or to provide extra arch supports or plug-in structures to transfer pressure concentration, they were all useful in diabetic foot care to prevent occurrence of ulceration. Overall, it is recommended that diabetic patients shall wear pressure-relieving insoles/shoes while walking.
\end{abstract}

KEY WORDS: diabetes mellitus, footwear, foot ulcer, plantar pressure

\section{EFICACITATEA ÎNCĂLȚĂMINTEI / BRANȚURILOR ÎN REDUCEREA PRESIUNII PLANTARE ÎN CAZUL DIABETICILOR: O META-ANALIZĂ}

REZUMAT. Întrucât rapoartele actuale au demonstrat o prevalență mai mare a ulcerelor piciorului la pacienții diabetici care suferă de complicații ale piciorului, prevenirea apariției ulcerațiilor a fost ținta principală în îngrijirea piciorului. În urma consensului clinic s-a introdus o varietate de produse pentru ameliorarea presiunii la pacienții cu diabet zaharat, iar clinicienii au prescris aceste produse pacienților și leau recomandat utilizarea acestora în viața de zi cu zi. Cu toate acestea, datele disponibile încă sunt controversate și este incert dacă aceste produse ar putea reduce efectiv presiunea plantară sau nu. Prin urmare, această meta-analiză a avut ca scop mai întâi să treacă în revistă toate constatările relevante din baza de date actuală și, în al doilea rând, să determine dacă branțurile / încălțămintea cu funcție de reducere a presiunii pot ameliora cu adevărat presiunea plantară și care sunt diferențele dintre produsele personalizate (încălțăminte / branțuri) și cele standard în ceea ce privește reducerea presiunii plantare. S-au căutat mai întâi articole indexate în Web of Science, Medline via OVID, CINAHL, SCOPUS, INFORMIT, Cochrane Central și EMBASE via OVID. Apoi s-au filtrat studiile observaționale care raportează efectul experimental al branțurilor / încălțămintei cu funcție de reducere a presiunii. Între timp, s-a stabilit ca rezultat primar media generală a maximelor de presiune plantară (MPP) și ca rezultate secundare, MPP în diferite regiuni plantare și MPP la branțuri / încălțăminte cu diferite modele structurale. Rezultatele arată că produsele de reducere a presiunii (încălțăminte / branțuri) au scăzut amplitudinea concentrației de presiune, iar efectul produselor personalizate și prefabricate în ceea ce privește ameliorarea presiunii a fost similar. Aceste constatări au sugerat că, indiferent dacă produsele de reducere a presiunii au fost fabricate la comandă sau prefabricate standard, dacă au fost concepute pentru a crește suprafața de contact în zona plantară, cum ar fi cele proiectate pe baza modelului plantar, sau pentru a oferi suport plantar suplimentar sau structuri „plug-in” pentru a transfera concentrația de presiune, toate produsele au fost utile în îngrijirea piciorului diabetic pentru a preveni apariția ulcerațiilor. În general, se recomandă ca pacienții cu diabet zaharat să poarte branțuri / încălțăminte pentru ameliorarea presiunii în timpul mersului.

CUVINTE CHEIE: diabet, încălțăminte, ulcerul piciorului, presiunea plantară

\section{EFFICACITÉ DES CHAUSSURES / SEMELLES DE DÉCHARGE SUR LA RÉDUCTION DE LA PRESSION PLANTAIRE DU PIED DIABÉTIQUE : UNE} MÉTA-ANALYSE

RÉSUMÉ. Étant donné que les rapports actuels ont démontré une prévalence plus élevée des ulcères du pied chez les patients diabétiques qui souffrent de complications du pied, la prévention des ulcères du pied était la principale cible des soins des pieds. Le consensus clinique a introduit une variété de produits anti-pression pour les patients diabétiques et les cliniciens ont prescrit ces produits à leurs patients et les ont recommandés dans la vie quotidienne. Cependant, les données disponibles étaient encore controversées et la question de savoir si ces produits pouvaient effectivement réduire la pression plantaire ou non était incertaine. Ainsi, cette méta-analyse visait d'abord à résumer tous les résultats pertinents de la base de données actuelle et, d'autre part, à explorer si les semelles / chaussures de décharge peuvent vraiment soulager la pression plantaire et quelles sont les différences entre les produits personnalisés (chaussures / semelles) et les produits standard pour réduire la pression plantaire. On a d'abord recherché des articles cités à partir de Web of Science, Medline via OVID, CINAHL, SCOPUS, INFORMIT, Cochrane Central et EMBASE via OVID. Ensuite, on a filtré les études observationnelles rapportant l'effet expérimental des semelles / chaussures de décharge. Pendant ce temps, on a défini le résultat principal en tant que pic de pression plantaire moyenne

* Correspondence to: Assoc. Prof. Dr. Jin Zhou. National Engineering Laboratory for Clean Technology of Leather Manufacture, Sichuan University; Chengdu 610065, P. R. China; Fax:008613880467494. zj_scu@scu.edu.cn 
(MPP) globale et les résultats secondaires en tant que MPP dans diverses régions plantaires et MPP au niveau des semelles / chaussures avec différentes conceptions de structure. Les résultats montrent que les produits de soulagement de la pression (chaussures / semelles) ont réduit I samplitude de la concentration de pression ; l'effet des produits sur mesure et préfabriqués sur le soulagement de la pression était similaire. Ces résultats suggèrent que peu importe que les produits de soulagement de la pression soient fabriqués sur mesure ou préfabriqués en standard, s'ils ont été conçus pour augmenter les zones de contact plantaires globales, telles que les produits conçus sur la base d'un modèle plantaire, ou pour fournir des supports plantaires supplémentaires ou des structures enfichables pour transférer la concentration de pression, ils étaient tous utiles dans les soins du pied diabétique pour éviter l'apparition d'ulcères. Dans l'ensemble, il est recommandé aux patients diabétiques de porter des semelles / chaussures anti-pression tout en marchant.

MOTS CLÉS : diabète, chaussure, ulcère du pied, pression plantaire

\section{INTRODUCTION}

More than 0.5 billion patients worldwide are diagnosed with diabetic mellitus (DM), which severely lowers the quality of life and even threatens the life of patients. DM cannot be cured and can only be controlled in a general level; however, poor control measures can result in complications, such as nephropathy and diabetic foot, which contribute to other serious consequences [1].

Diabetic foot, usually found in the lower limbs, is characterised by diabetic sensory neuropathy, limited joint activity, poor immune function, peripheral artery disease, foot ulcer and Charcot joint disease [2]. These complications provide an ideal environment for unrecognised tissue injury, which leads to ulceration [3]. Currently, the prevalence of foot ulcer ranges from $4 \%$ to $10 \%$ in the DM group, and the annual incidence by population ranges from $1.0 \%$ to $4.1 \%$ [4]. Furthermore, foot ulcers are the main cause of amputation, and the possibility of ulceration is 10-30 times higher in patients with DM than in healthy individuals [5, 6]. In fact, one person is amputated every $30 \mathrm{~s}$ in the world because of diabetes [7].

Clinical consensus approved that abnormal pressure and pressure concentration are highly correlated with ulceration $[8,9]$. Those abnormal pressures might be attributed to foot deformities, wearing unsuitable shoes or trauma caused by accident. Sites with abnormal pressure then develop muscle/soft tissue constrains, which might further deteriorate as pressure ulcers and even amputations. According to existing literature, the foot pressure of patients with diabetes is higher than that of people without diabetes [10-13]. In particular, ulcer sites, either the new one or with previous ulcer history, are recorded with high pressure distribution [10, 13]. Hence, avoiding high pressure load and implementing pressure relief are the primary tasks in diabetic foot care.
Protective shoes and insoles are prescribed to patients with DM because they lower pressure amplitudes and thus avoid foot ulcers [14]. However, a descriptive study following ulcerated patients over 2 years found that re-ulceration occurs in $72 \%$ of patients who resumed wearing their own footwear compared with $26 \%$ of patients who continued wearing prescribed footwear [15]. Other studies disclosed the positive effectiveness of various protective shoes/insoles on pressure relief [1618]. Thereby, the International Consensus for Diabetic Foot [19] suggested that wearing correct shoes/insoles is a direct and effective protocol in diabetic foot care. However, a few controversial outcomes were observed in the literature [20]. In specific, (1) whether or not pressurerelieving products (shoes/insoles) actually lower the pressure concentration under feet and (2) whether or not customised products (shoes/ insoles) are superior to standard pressurerelieving ones remain uncertain.

Therefore, this study assessed the current literature by meta-analysis and then quantitatively evaluated the pressure-relieving effect of shoes and insoles and those with varied design characteristics, such as custom made or standard one.

\section{METHODS}

\section{Search Strategy and Quality Assessment}

The following databases published until $18^{\text {th }}$ March 2019 were selected: Web of Science (1994-2018), Medline via OVID (1994-2018), CINAHL (1994-2018), SCOPUS (1994-2018), INFORMIT, Cochrane Central (2000-2018) and EMBASE via OVID (1994-2018). A primary author conducted the searching action; thereafter, this author repeatedly searched in August 2019 to identify any new articles of relevance. Keywords were elected according to a meeting among authors of this study: 'diabetes*', 'diabetic foot', 
'shoe*', 'pressure*', 'insole', 'ulcer', 'relieving', 'offload*', 'random', 'custom-made' and 'prevention'.

Two blinded authors applied the tools in Review Manager (Version 5.3, Copenhagen: The Nordic Cochrane Centre, The Cochrane Collaboration, 2014) for risk of bias assessment. A quality assessment tool was also adapted from validated measures with addition of questions specific to the pressure-relieving function of shoes/insoles [21]. Quality scores of $\geq 45,30-45$, 20-30 and $\leq 20$ were defined as excellent, good, fair and poor, respectively [10]. A primary author checked both records of risk of bias and quality of studies for consistency.

\section{Study Selection}

Studies were included in the meta-analysis if they met all the below inclusion criteria. Potential studies identified for inclusion were reviewed independently by two authors using those inclusion criteria. Group discussions were held to resolve any disagreements in the inclusion of studies.

- An observational study;

- Subjects included had no current ulcers or ulcers in their feet already recovered;

- The study was reported in or available in the English language;

- Plantar pressure values were reported in two groups: one included pressurerelieving shoes/insoles, including custom-made and standard products, and the other included control products.

- Plantar pressure values were reported as the mean peak plantar pressure (MPP) in any acceptable pressure unit $\left(\mathrm{KPa}, \mathrm{N} / \mathrm{kg}^{2}\right.$ or similar);

- Overall plantar pressure or regional ones, such as fore foot, mid foot and rear foot were reported

- Experimental shoes or insoles were reported with details.

- Studies were excluded if they meet any of the following criteria:

- Other pressure-relieving protocols rather than insoles/shoes, such as callus debridement and podiatry.

- Foot pressure data did not provide extractable mean and standard deviation (SD);
- Foot pressure data were not provided by sufficiently large samples. Studies only reported one person's data;

- No randomised experiments were conducted in the study;

- Only pressure plate measures were reported, as pressure plate recorded the pressure distribution of outsoles.

- Full-text manuscripts could not be acquired.

\section{Primary and Secondary Outcomes}

Three primary outcomes were set up: overall MPP, MPP in pressure-relieving insoles and MPP in pressure-relieving shoes. Then, seven secondary outcomes were nominated: MPP at the fore foot, MPP at the mid foot, MPP at the rear foot, MPP in custom-made insoles, MPP in standard pressure-relieving insoles, MPP in custom-made shoes and MPP in standard pressure-relieving shoes. We defined that the toes, MTH1-5, hallux were included into fore foot regions and the heel was divided into rear foot regions.

\section{Data Extraction and Synthesis}

Data extraction was first completed by one primary author, and the extracted data were checked by another primary author for any omissions. At first, descriptive data such as age, sample size, types and structures of shoes/insoles were recorded for each study. Afterwards, numerical data (mean and SD) for each plantar pressure variable were carefully identified and extracted. When studies assessed insoles/shoes with a variety of structure designs or modifications and more than one comparison were reported, each comparison was extracted and included for analysis. Considering that plantar pressure data were measured and reported in terms of feet unit, we extracted each foot data. Anatomical locations were unspecified, and we defaulted that all the included studies have a unified criterion for anatomical definition.

\section{Statistical Methods}

Standardised mean differences (SMD) were calculated by Cohen's $d$ [22] and then input in meta-analyses. Results were expressed as SMD with $95 \%$ confidence intervals $(95 \% \mathrm{Cl})$ 
and $p$-values. Furthermore, weighted means (according to the sample size factor) were randomly calculated for reported variables. The $Z$ test and 12 statistics were used to assess statistical heterogeneity between studies. 12 with values of $25 \%, 50 \%$ and $75 \%$ were considered as low, moderate and high heterogeneity, respectively [23]. All meta-analysis models were executed by the primary author using the software package of Review Manager.

\section{RESULTS}

\section{Search Results}

The flowchart of literature filtering is shown in Figure 1, and 18 studies were retained for further analysis [20, 24-40].

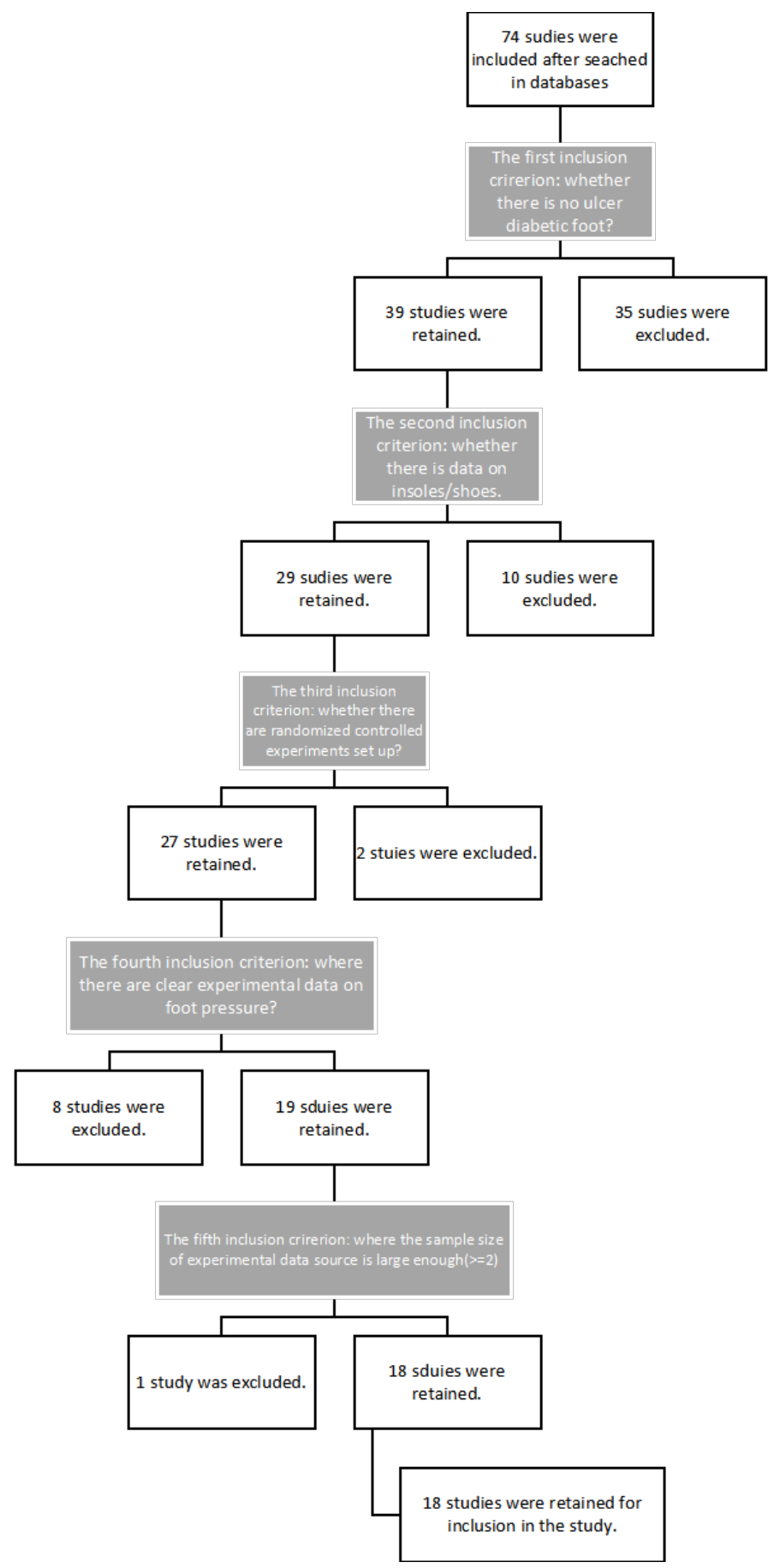

Figure 1. Flowchart of filtering of literature 


\section{Primary Outcomes}

Overall MPP was reported by all 17 comparisons from 8 studies. Meta-analysis combining the data from 17 comparisons (pressure-relieving insoles $\mathrm{n}=714$; standard control insoles $n=713$ ) suggested that pressure- relieving shoes/insoles significantly reduced the MPP for patients with diabetes in comparison with the control ones $(\mathrm{SMD}=-0.74,95 \% \mathrm{Cl}$ $=-1.00-(-0.49), Z=5.70, P<0.0001)$. The heterogeneity between studies was high $(12=$ $80 \%$ ) (Figure 2).

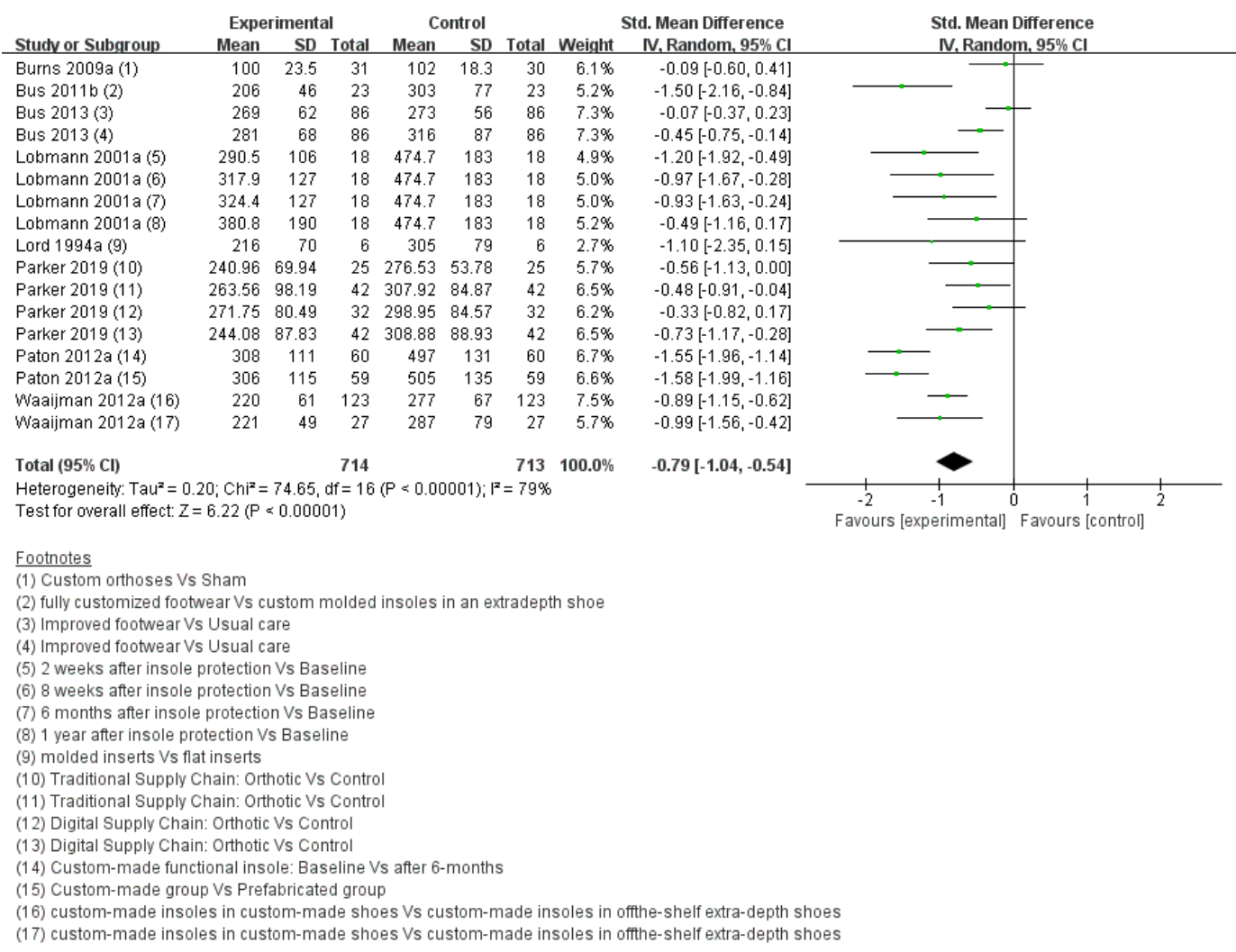

Figure 2. Forest plot of the overall Peak Plantar Pressure (MPP)

Pressure-relieving insoles significantly reduced the MPP for patients with diabetes in comparison with the control shoes (SMD $=-1.19$, $95 \% \mathrm{Cl}=-1.45-(-0.93), \mathrm{Z}=9.01, \mathrm{P}<0.00001$, $12=87 \%)$. Similarly, pressure-relieving insoles significantly reduced the MPP for patients with diabetes in comparison with the control insoles $(\mathrm{SMD}=-0.42,95 \% \mathrm{Cl}=-0.55-(-0.29), \mathrm{Z}=6.35$, $\mathrm{P}<0.00001,12=85 \%)$.

\section{Secondary Outcomes}

\section{MPP at Various Plantar Regions}

MPP at the forefoot was significantly lowered (SMD $=-0.70,95 \% \mathrm{Cl}=-0.85-(-0.54), \mathrm{Z}$ $=8.79, \mathrm{P}<0.00001)$. The heterogeneity between studies was high $(12=85 \%)$.
MPP at the rear foot was also significantly attenuated by pressure-relieving insoles (SMD $=-1.00,95 \% \mathrm{Cl}=-1.27-(-0.74), \mathrm{Z}=7.41, \mathrm{p}<$ $0.00001,12=73 \%$ ).

Although a slight pressure-relieving effect on the mid foot area was observed in contrast with the control insoles $(\mathrm{SMD}=0.00,95 \% \mathrm{Cl}=$ $-0.18-0.19, Z=0.03, P=0.97)$, heterogeneity between studies was low $(12=46 \%)$.

\section{MPP at Various Shoes}

MPP with custom-made shoes was divided by three studies, and four comparisons were reported. Meta-analysis combining the data from four comparisons (pressure-relieving shoes $\mathrm{n}=211$; standard control shoes $\mathrm{n}=211$ ) implied that with the favour of custom-made shoes, the 
MPP with custom-made shoes was significantly lowered $(\mathrm{SMD}=-0.75,95 \% \mathrm{Cl}=-1.33-(-0.17)$,
$\mathrm{Z}=2.52, \mathrm{P}=0.01)$. The heterogeneity between studies was high $(12=86 \%)$ (Figure 3 ).

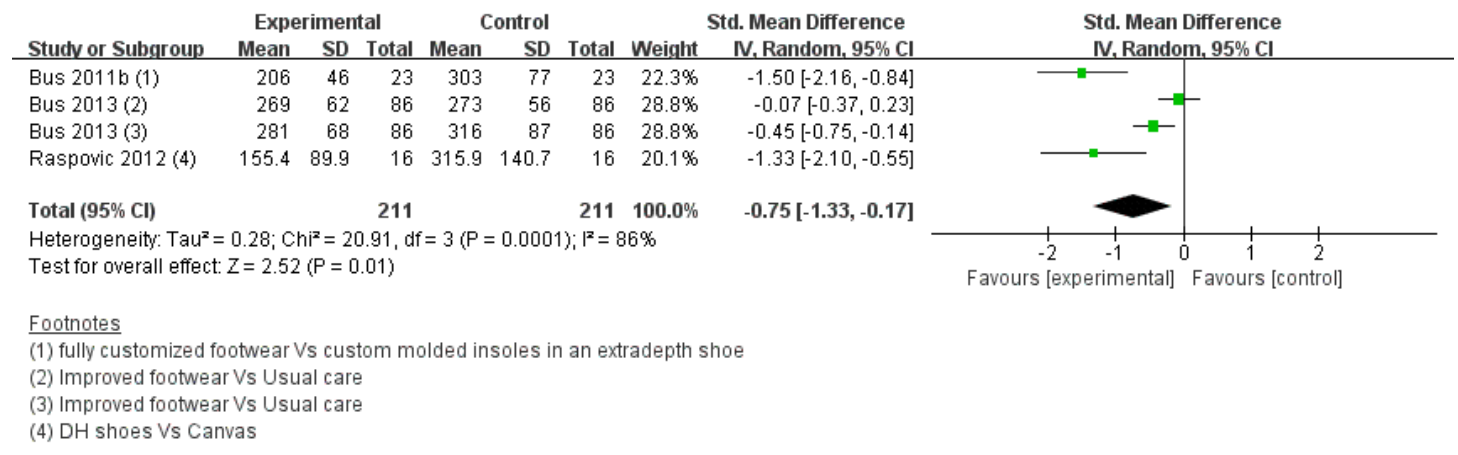

Figure 3. Forest plot of the Peak Plantar Pressure (MPP) in custom-made pressure-relieving shoes

The same tendency was also found for standard pressure-relieving shoes and metaanalysis combining data 49 comparisons from three studies (pressure-relieving insoles $n=1096$; standard control insoles $n=1096$ ) indicated that the MPP under the standard insoles was also slightly attenuated by pressure-relieving insoles $(\mathrm{SMD}=-1.34,95 \% \mathrm{Cl}=-1.60-(-1.07), \mathrm{Z}=9.89$, $p<0.00001,12=87 \%$ ) (Figure 4). 


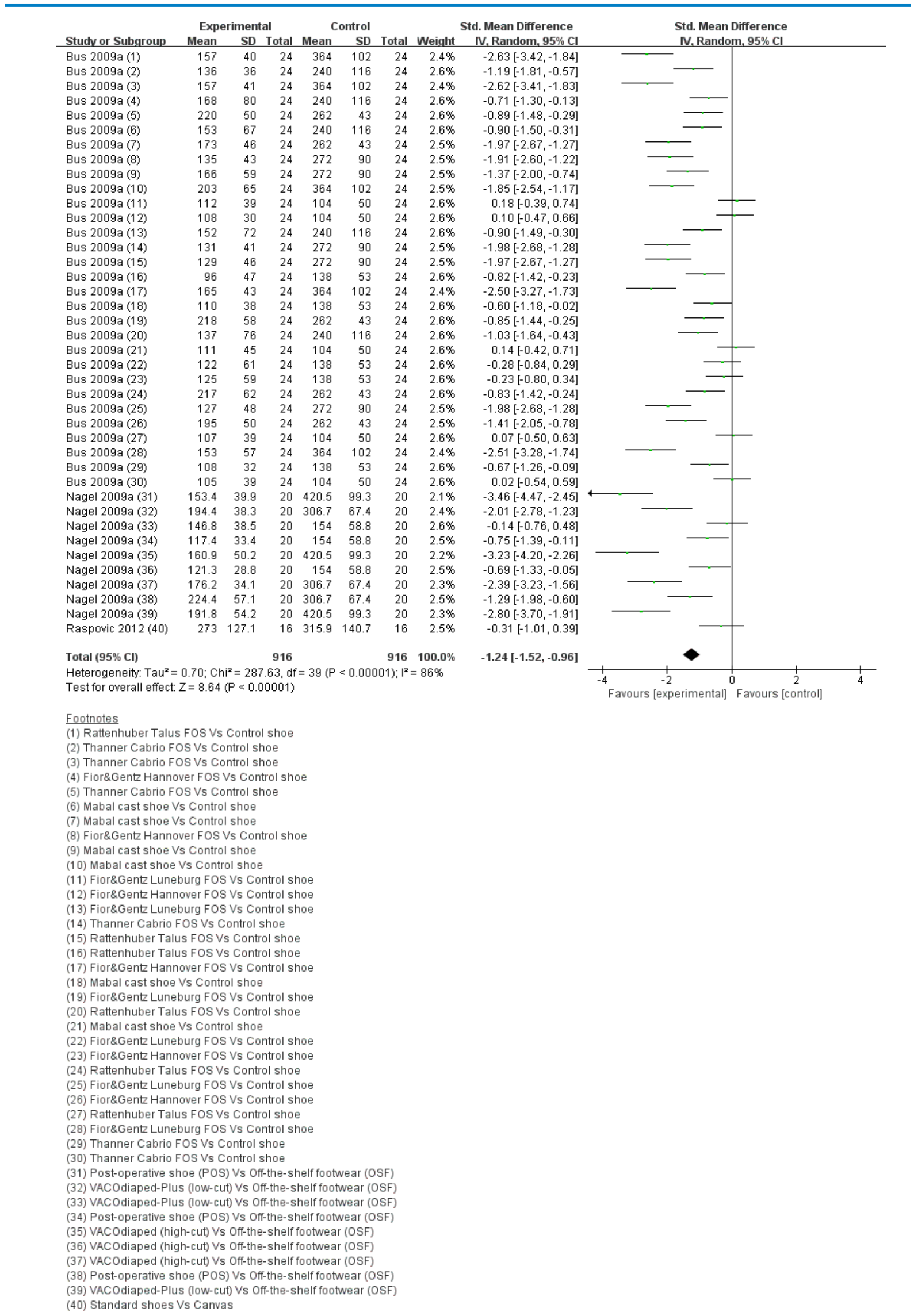

Standard shoes Vs Canvas

Figure 4. Forest plot of the Peak Plantar Pressure (MPP) in standard pressure-relieving shoes 


\section{MPP at Various Insoles}

The insoles can be classified into custommade and standard ones. The MPP under the custom-made insoles was divided by 10 studies, and 33 comparisons were reported. Metaanalysis combining data from 33 comparisons (pressure-relieving insoles $\mathrm{n}=2894$; standard control insoles $n=3056$ ) implied that the MPP under custom-made insoles was significantly lowered $(\mathrm{SMD}=-0.48,95 \% \mathrm{Cl}=-0.61-(-0.34), \mathrm{Z}$ $=6.73, \mathrm{P}<0.00001)$. The heterogeneity between studies was high $(12=84 \%)$ (Figure 5 ).

\begin{tabular}{|c|c|c|c|c|c|c|c|}
\hline \multirow[b]{2}{*}{ Studv or Subgroup } & \multicolumn{3}{|c|}{ Experimental } & \multicolumn{3}{|c|}{ Control } & \multirow[b]{2}{*}{ Weight } \\
\hline & Mean & SD & Total & Mean & & Total & \\
\hline Arts 2015a (1) & 209 & 55 & 67 & 271 & 66 & 67 & $2.7 \%$ \\
\hline Ants $2015 a$ (2) & 209 & 37 & 16 & 241 & 30 & 16 & $1.6 \%$ \\
\hline Arts $2015 a$ (3) & 235 & 70 & 13 & 284 & 108 & 13 & $1.5 \%$ \\
\hline Arts $2015 a(4)$ & 221 & 50 & 39 & 258 & 48 & 39 & $2.4 \%$ \\
\hline Arts 2015a (5) & 239 & 53 & 26 & 258 & 50 & 26 & $2.1 \%$ \\
\hline Arts 2015a (6) & 268 & 72 & 30 & 306 & 79 & 30 & $2.2 \%$ \\
\hline Arts 2015a (7) & 212 & 40 & 25 & 251 & 47 & 25 & $2.0 \%$ \\
\hline Arts 2015a (8) & 264 & 78 & 27 & 283 & 52 & 27 & $2.2 \%$ \\
\hline Arts 2015a (9) & 238 & 53 & 24 & 281 & 59 & 24 & $2.0 \%$ \\
\hline Arts $2015 a(10)$ & 212 & 52 & 58 & 260 & 54 & 58 & $2.7 \%$ \\
\hline Arts 2015a (11) & 210 & 48 & 25 & 250 & 66 & 25 & $2.1 \%$ \\
\hline Arts 2015a (12) & 212 & 51 & 52 & 280 & 56 & 52 & $2.5 \%$ \\
\hline Burns $2009 a(13)$ & 102 & 18.3 & 30 & 100 & 23.5 & 31 & $2.3 \%$ \\
\hline Bus 2011b (14) & 206 & 46 & 23 & 303 & 77 & 23 & $1.8 \%$ \\
\hline Hellstrand 2014 (15) & 259 & 114 & 142 & 250 & 137 & 154 & $3.2 \%$ \\
\hline Hellstrand 2014 (16) & 127 & 65 & 142 & 163 & 88 & 154 & $3.1 \%$ \\
\hline Hellstrand 2014 (17) & 193 & 86 & 142 & 202 & 85 & 154 & $3.2 \%$ \\
\hline Hellstrand 2014 (18) & 189 & 85 & 143 & 238 & 130 & 154 & $3.2 \%$ \\
\hline Hellstrand 2014 (19) & 206 & 118 & 143 & 250 & 137 & 154 & $3.2 \%$ \\
\hline Hellstrand 2014 (20) & 144 & 83 & 143 & 163 & 88 & 154 & $3.2 \%$ \\
\hline Hellstrand 2014 (21) & 98 & 47 & 143 & 99 & 69 & 154 & $3.2 \%$ \\
\hline Hellstrand 2014 (22) & 95 & 44 & 142 & 99 & 69 & 154 & $3.2 \%$ \\
\hline Hellstrand 2014 (23) & 178 & 64 & 143 & 242 & 88 & 154 & $3.1 \%$ \\
\hline Hellstrand 2014 (24) & 171 & 57 & 142 & 242 & 88 & 154 & $3.1 \%$ \\
\hline Hellstrand 2014 (25) & 251 & 118 & 143 & 283 & 119 & 154 & $3.2 \%$ \\
\hline Hellstrand 2014 (26) & 217 & 95 & 142 & 238 & 130 & 154 & $3.2 \%$ \\
\hline Hellstrand $2014(27)$ & 259 & 95 & 142 & 283 & 119 & 154 & $3.2 \%$ \\
\hline Hellstrand 2014 (28) & 197 & 89 & 143 & 202 & 85 & 154 & $3.2 \%$ \\
\hline Lobmann 2001a (29) & 380.8 & 190 & 18 & 474.7 & 183 & 18 & $1.8 \%$ \\
\hline Lord 1994a (30) & 216 & 70 & 6 & 305 & 79 & 6 & $0.8 \%$ \\
\hline Owings $2008 \mathrm{a}$ (31) & 200 & 46 & 23 & 245 & 63 & 23 & $2.0 \%$ \\
\hline Owings 2008a (32) & 127 & 38 & 23 & 168 & 53 & 23 & $2.0 \%$ \\
\hline Owings $2008 \mathrm{a}$ (33) & 178 & 59 & 23 & 211 & 79 & 23 & $2.0 \%$ \\
\hline Parker 2019 (34) & 244.08 & 87.83 & 42 & 308.88 & 88.93 & 42 & $2.5 \%$ \\
\hline Parker 2019 (35) & 263.56 & 98.19 & 42 & 307.92 & 84.87 & 42 & $2.5 \%$ \\
\hline Parker 2019 (36) & 240.96 & 69.94 & 25 & 276.53 & 53.78 & 25 & $2.1 \%$ \\
\hline Parker 2019 (37) & 271.75 & 80.49 & 32 & 298.95 & 84.57 & 32 & $2.3 \%$ \\
\hline Paton 2012a (38) & 308 & 111 & 60 & 497 & 131 & 60 & $2.6 \%$ \\
\hline Waaijman 2012a (39) & 220 & 61 & 123 & 277 & 67 & 123 & $3.1 \%$ \\
\hline Waaijman 2012a (40) & 221 & 49 & 27 & 287 & 79 & 27 & $2.1 \%$ \\
\hline Total (95 & & & 2007 & & & 056 & $0.0 \%$ \\
\hline
\end{tabular}

Std. Mean Difference

Heterogeneity: $\mathrm{Tau}^{2}=0.12 ; \mathrm{Chi}^{2}=204.87, \mathrm{df}=39(\mathrm{P}<0.00001) ; \mathrm{I}^{2}=81 \%$

IV. Random, $95 \% \mathrm{C}$

$-1.01[-1.38,-0.65]$

$-0.52[-1.31,0.26]$

$-0.75[-1.21,-0.29]$

$-0.36[-0.91,0.19]$

$-0.88[-1.46,-0.30]$

$-0.28[-0.82,0.25]$

$-0.75[-1.34,-0.17]$

$-0.75[-1.34,-0.17]$

$-0.68[-1.25,-0.11]$

$-1.26[-1.68,-0.84]$

$0.09[-0.41,0.60]$

$-1.50[-2.16,-0.84]$

$0.07[-0.16,0.30]$

$-0.46[-0.69,-0.23]$

$-0.11[-0.33,0.12]$

$-0.44[-0.67,-0.21]$

$-0.34[-0.57,-0.11]$

$-0.22[-0.45,0.01]$

$-0.02[-0.24,0.21]$

$-0.07[-0.30,0.16]$

$-0.82[-1.06,-0.59]$

$-0.95[-1.19,-0.71]$

$-0.27[-0.50,-0.04]$

$-0.18[-0.41,0.05]$

$-0.22[-0.45,0.01]$

$-0.06[-0.29,0.17]$

$-0.49[-1.16,0.17]$

$-1.10[-2.35,0.15]$

$-0.80[-1.40,-0.20]$

$-0.87[-1.48,-0.27]$

$-0.47[-1.05,0.12]$

$-0.73[-1.17,-0.28]$

$-0.48[-0.91,-0.04]$

$-0.56[-1.13,0.00]$

$-0.33[-0.82,0.17]$

$-1.55[-1.96,-1.14]$

$-0.89[-1.15,-0.62]$
$-0.99[-1.56,-0.42]$

$-0.55[-0.68,-0.42]$ IV Random. $95 \% \mathrm{CI}$

Test for overall effect: $Z=8.39(\mathrm{P}<0.00001)$

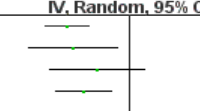

Footnotes

(1) fully custom-made footwear Vs semi-custom-made footwear

(3) fully custom-made footwear Vs semi-custom-made footwear

(4) fully custom-made footwear Vs semi-custom-made footwear

(5) fully custom-made footwear Vs semi-custom-made footwear

(6) fully custom-made footwear Vs semi-custom-made footwear

(6) fully custom-made footwear Vs semi-custom-made footwear

(8) fully custom-made footwear Vs semi-custom-made footwear

(9) fully custom-made footwear Vs semi-custom-made footwear

(10) fully custom-made footwear Vs semi-custom-made footwear

(11) fully custom-made footwear Vs semi-custom-made footwear

(12) fully custom-made footwear Vs semi-custom-made footwear

(13) Custom orthoses Vs Sham

(14) fully customized footwear Vs custom molded insoles in an extradepth sho

(15) 55 shore EVA insoles Vs prefabricated insoles

(16) 55 shore EVA insoles Vs prefabricated insoles

(17) 55 shore EVA insoles Vs prefabricated insoles

(18) 35 shore EVA insoles Vs prefabricated insoles

(19) 35 shore EVA insoles Vs prefabricated insoles

(20) 35 shore EVA insoles Vs prefabricated insoles

21) 35 shore EVA insoles Vs prefabricated insoles

(22) 55 shore EVA insoles Vs prefabricated insoles

(23) 35 shore EVA insoles Vs prefabricated insoles

(24) 55 shore EVA insoles Vs prefabricated insoles

25) 35 shore EVA insoles Vs prefabricated insoles

26) 55 shore EVA insoles Vs prefabricated insoles

27) 55 shore EVA insoles Vs prefabricated insoles

28) 35 shore EVA insoles Vs prefabricated insoles

(29) 1 year after insole protection Vs
(30) molded inserts $V$ s flat inserts

(30) molded inserts Vs flat inserts
(31) insoles X in the rigid shoes Vs insoles X in the fiflexible shoes

(31) insoles $X$ in the rigid shoes Vs insoles $X$ in the fiflexible shoes

(32) insoles $Z$ in the rigid shoes Vs insoles $X$ in the ffflexible shoes

(34) Digital Supply Chain: Orthotic Vs Control

(34) Digital Supply Chain: Orthotic Vs Control

56) Tradtional Supply Chain. Orholic Vs Contro

(36) Traditional Supply Chain: Orthotic Vs Cont

(38) Custom-made functional insole: Baseline Vs after 6-months

(39) custom-made insoles in custom-made shoes Vs custom-made insoles in offthe-shelf extra-depth shoes

(40) custom-made insoles in custom-made shoes Vs custom-made insoles in offthe-shelf extra-depth shoes

Figure 5. Forest plot of the Peak Plantar Pressure (MPP) in custom-made pressure-relieving insoles 
Similarly, the MPP under the standard insoles was also slightly attenuated $(\mathrm{SMD}=-0.43$, $95 \% \mathrm{Cl}=-0.78-(-0.09), \mathrm{Z}=2.46, \mathrm{p}=0.01,12=$
$85 \%)$ on the basis of 28 comparisons (pressurerelieving insoles $n=553$; standard control insoles $n=537$ ) from four studies (Figure 6).

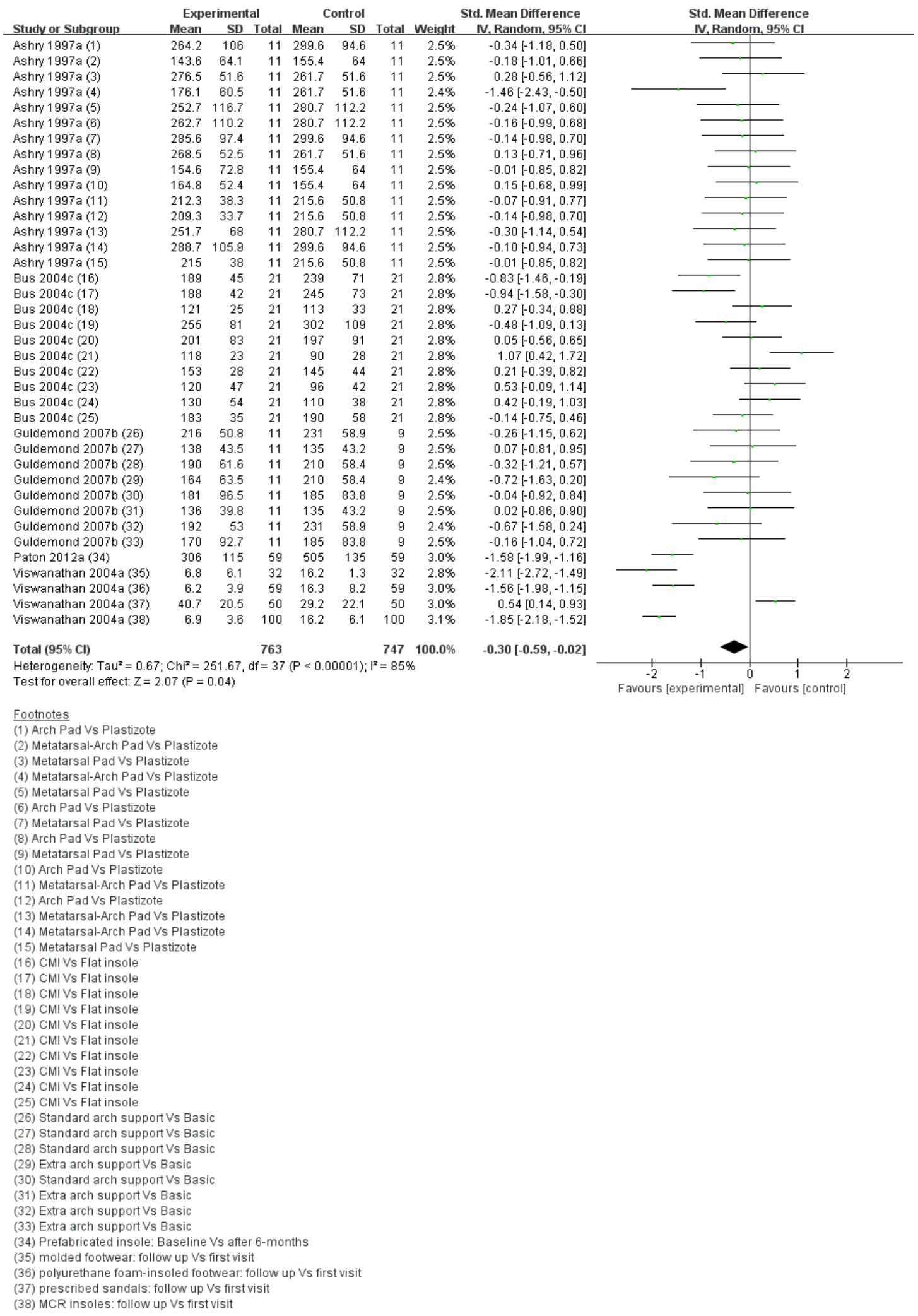

Figure 6. Forest plot of the Peak Plantar Pressure (MPP) in standard pressure-relieving insoles 


\section{DISCUSSION}

In this study, we used a meta-analysis to evaluate 18 studies and 346 comparisons between pressure-relieving products (shoes/ insoles) and standard ones. Then, we analysed the overall MPP, MPP at various plantar regions and MPP at insoles/shoes with various structure designs. Our findings confirmed several positive agreements that pressure-relieving products (shoes/insoles) really lower the amplitude of pressure concentration. In addition, the pressure-relieving effects of custom-made and prefabricated products were similar.

Abnormal peak pressure is considered a major cause of diabetic foot ulcer; thus, pressure relief is a fundamental measure in diabetic care $[19,41,42]$. According to foot biomechanics, foot is the only body part contacting with the ground, where a large amount of ground reaction forces is concentrated on. Two principles are followed in lowering plantar pressure: one is increasing contact areas, and the other is transferring the peak pressure from risk areas to relatively safe ones, such as areas with occurrence of foot deformities, abnormal gait, wearing wrong shoes or shoes with foreign bodies (e.g. scree) [25].

In the first situation, current studies directly approved that plantar pressures are significantly reduced by using pressure-relieving products $[43,44]$, where experiment shoes and insoles performed closely. Moreover, two types of product designs were available: one was custom made $[45,46]$, and the other was prefabricated standard or modular assembled [31, 35]. Usually, the custom-made ones use static or dynamic foot impressions in a foam box or by digital 3D scan, from which a positive plaster cast of the plantar surface is created [28]. The custom-made shoes or insoles were developed based on the patient's plantar surface. This style of products has the largest contact area with the foot; thus, the overall MPP can be distributed.

In the second situation, extra structure designs were provided to both shoes and insoles. Standard pressure-relieving products provide extra structures, such as arch support, heel cup, wedges, metatarsal pad and hollow treatment $[18,47,48]$, and they also aim to achieve pressure exchange. By contrast, standard pressurerelieving products $(S M D=-1.34$ for shoes and $S M D=-0.43$ for insole) performed superior than custom-made ones (SMD $=-0.75$ for shoes and SMD $=-0.48$ for insole). Thereby, we postulated that efficient pressure-relieving measures should first consider shoes before insoles. These findings once again support the description in international consensus for diabetic foot [19]: wearing the pressure-relieving shoes/insoles can effectively reduce plantar pressure and avoid ulceration.

By considering the heterogeneity of our results, majority of findings displayed a moderate-to-high heterogeneity $(12>70 \%)$. The 12 value at the mid foot was lower than $50 \%$ because this area beard extra loading by the arch support structure which transferred pressure from other parts of plantar regions. The high heterogeneity further supported validity of this meta-analysis [10].

Risk of bias for the included studies was assessed. The overall agreement between the two quality assessors was good, with the variation of scores ranging from zero to three points. In general, all studies used an appropriate study design and accounted for potential confounders. However, one study did not report data on a primary outcome measure for at least $85 \%$ of the participants, none of the studies calculated the power of the sample and only two studies identified the presence of PAD or excluded those with PAD. The highest score for the method-and participant-specific questions was given to the study which addressed issues such as number of steps used in measurements, number of walking trials and the measurement of factors which potentially affected plantar pressure, such as diabetes duration and type of diabetes [29].

This study has some limitations. In a single study, researchers reported two measures between pressure-relieving and control products. One was two or more types of pressure-relieving shoes versus control shoes (See [31, 32]); the other was continuing modification for custommade insoles (See [34, 49]). Regarding the two conditions, we counted each measure as individual record and input each of them in the meta-analysis. This method might introduce bias by increasing the sample size.

\section{CONCLUSION}

This meta-analysis confirmed that pressure-relieving shoes/insoles perform well in 
lowering plantar pressure distribution. Pressurerelieving products, regardless if they are custom made or pre-fabricated, can prevent ulceration and help in diabetic foot care if they are designed to increase overall plantar contact areas or to provide extra arch supports or plug-in structures to transfer pressure concentration.

\section{Acknowledgement}

The authors appreciate all the children and adults who participated in this study. This work was supported by Sichuan Science and Technology Program: 2020YFH0068. We also thank the National Natural Science Foundation of China (31700813).

\section{Conflict of Interest Statement}

There are no conflicts of interest with other authors and institutions. No subjects or animals were included in this study. Neither participants nor informed consent were included in the study.

\section{REFERENCES}

1. Bus, S.A., van Netten, J.J., Lavery, L.A., Monteiro-Soares, M., Rasmussen, A., Jubiz, Y., Price, P.E., IWGDF guidance on the prevention of foot ulcers in at-risk patients with diabetes, Diabetes Metab Res Rev, 2016, 32, 16-24, WOS: 000369134100004, https:// doi.org/10.1002/dmrr.2696.

2. Waaijman, R., de Haart, M., Arts, M.L.J., Wever, D., Verlouw, A.J.W.E., Nollet, F., Bus, S.A., Risk Factors for Plantar Foot Ulcer Recurrence in Neuropathic Diabetic Patients, Diabetes Care, 2014, 37, 6, 1697-1705, WOS: 000337746100047, https://doi.org/10.2337/ dc13-2470.

3. Lavery, L.A., Oz, O.K., Bhavan, K., Wukich, D.K., Diabetic Foot Syndrome in the Twenty-First Century, Clin Podiatr Med Surg, 2019, 36, 3, 355-359, MEDLINE: 31079602, https://doi. org/10.1016/j.cpm.2019.02.002.

4. Singh, N., Armstrong, D.G., Lipsky, B.A., Preventing foot ulcers in patients with diabetes, J Am Med Assoc, 2005, 293, 2, 217228, WOS: 000226171000038, https://doi. org/10.1001/jama.293.2.217.

5. Siitonen, O.I., Niskanen, L.K., Laakso, M., Siitonen, J.T., Pyörälä, K., Lower-Extremity
Amputations in Diabetic and Nondiabetic Patients: A population-based study in eastern Finland, Diabetes Care, 1993, 16, 1, 16-20, https://doi.org/10.2337/diacare.16.1.16.

6. Trautner, C., Haastert, B., Giani, G., Berger, M., Incidence of lower limb amputations and diabetes, Diabetes Care, 1996, 19, 9, 1006-1009, https://doi.org/10.2337/ diacare.19.9.1006.

7. Boulton, A.J.M., Vileikyte, L., RagnarsonTennvall, G., Apelqvist, J., The global burden of diabetic foot disease, Lancet, 2005, 366, 9498, 1719-1724, WOS: 000233206400028, https:// doi.org/10.1016/S0140-6736(05)67698-2.

8. Veves, A., Murray, H.J., Young, M.J., Boulton, A.J.M., The risk of foot ulceration in diabetic patients with high foot pressure: a prospective study, Diabetologia, 1992, 35, 7, 660-663, https://doi.org/10.1007/BF00400259.

9. Stess, R.M., Jensen, S.R., Mirmiran, R., The role of dynamic plantar pressures in diabetic foot ulcers, Diabetes Care, 1997, 20, 5, 855, https://doi.org/10.2337/diacare.20.5.855.

10. Fernando, M.E., Crowther, R.G., Pappas, E., Lazzarini, P.A., Cunningham, M., Sangla, K.S., Buttner, P., Golledge, J., Plantar Pressure in Diabetic Peripheral Neuropathy Patients with Active Foot Ulceration, Previous Ulceration and No History of Ulceration: A Meta-Analysis of Observational Studies, PLoS One, 2014, 9, 6, 10, WOS: 000340947700054 , https://doi. org/10.1371/journal. pone.0099050.

11. Bus, S.A., Innovations in plantar pressure and foot temperature measurements in diabetes, Diabetes Metab Res Rev, 2016, 32, 221226, WOS: 000369134100023 , https://doi. org/10.1002/dmrr.2760.

12. Pitei, D.L., Foster, A., Edmonds, M., The effect of regular callus removal on foot pressures, J Foot Ankle Surg, 1999, 38, 4, 251-306, MEDLINE: 10464719, https://doi. org/10.1016/S1067-2516(99)80066-0.

13. Owings, T.M., Apelqvist, J., Stenstrom, A., Becker, M., Bus, S.A., Kalpen, A., Ulbrecht, J.S., Cavanagh, P.R., Plantar pressures in diabetic patients with foot ulcers which have remained healed, Diabet Med, 2009, 26, 11, 1141-1146, WOS: 000271493900010, https:// doi.org/10.1111/j.1464-5491.2009.02835.x.

14. McCabe, C., Stevenson, R.C., Dolan, A.M., Evaluation of a diabetic foot screening and 
protection program, Diabet Med, 1998, 15, 1, 80-84, https://doi.org/10.1002/ (SICI)1096-9136(199801)15:1\%3C80::AIDDIA517\%3E3.0.CO;2-K.

15. Reiber, G.E., Who Is At Risk of Limb Loss And What To Do About It?, J Rehabil Res Dev, 1994, 31, 4, 357-362.

16. Praet, S.F.E., Louwerens, J.W.K., The influence of shoe design on plantar pressures in neuropathic feet, Diabetes Care, 2003, 26, 2, 441-445, WOS: 000185505000032 , https:// doi.org/10.2337/diacare.26.2.441.

17. Cheung, J.T.-M., Zhang, M., Parametric design of pressure-relieving foot orthosis using statistics-based finite element method, Med Eng Phys, 2008, 30, 3, 269277, WOS: 000254685000001 , https://doi. org/10.1016/j.medengphy.2007.05.002.

18. Actis, R.L., Ventura, L.B., Lott, D.J., Smith, K.E., Commean, P.K., Hastings, M.K., Mueller, M.J., Multi-plug insole design to reduce peak plantar pressure on the diabetic foot during walking, Med Biol Eng Comput, 2008, 46, 4, 363-371, WOS: 000254237800007, https:// doi.org/10.1007/s11517-008-0311-5.

19. Connor, H., International Consensus on the Diabetic Foot - Book review, Pract Diabetes, 2000, 17, 6, 642A, https://doi.org/10.1002/1528$252 \times(200009) 17: 6 \% 3$ C194::AID PDI94\%3E3.0.CO;2-G.

20. Lobmann, R., Kayser, R., Kasten, G., Kasten, U., Kluge, K., Neumann, W., Lehnert, H., Effects of preventative footwear on foot pressure as determined by pedobarography in diabetic patients: a prospective study, Diabet Med, 2001, 18, 4, 314-319, WOS: 000169753600010, https://doi.org/10.1046/ j.1464-5491.2001.00482.x.

21. Sanderson, S., Tatt, I.D., Higgins, J.P.T., Tools for assessing quality and susceptibility to bias in observational studies in epidemiology: a systematic review and annotated bibliography, Int J Epidemiol, 2007, 36, 666676, https://doi.org/10.1093/ije/dym018.

22. Cohen, J., Statistical Power Analysis for the Behavioral Sciences, Lawrence Erlbaum Associates, 1988.

23. Fernando, M.E., Crowther, R.G., Pappas, E., Lazzarini, P.A., Cunningham, M., Sangla, K.S., Buttner, P., Golledge, J., Plantar pressure in diabetic peripheral neuropathy patients with active foot ulceration, previous ulceration and no history of ulceration: a meta-analysis of observational studies, PLoS One, 2014, 9, 6, e99050, https://doi.org/10.1371/journal. pone.0099050.

24. Raspovic, A., Landorf, K.B., Gazarek, J., Stark, M., Reduction of peak plantar pressure in people with diabetes-related peripheral neuropathy: an evaluation of the DH Pressure Relief Shoe (TM), J Foot Ankle Res, 2012, 5, WOS: 000310812500002, https://doi. org/10.1186/1757-1146-5-25.

25. Bus, S.A., Ulbrecht, J.S., Cavanagh, P.R., Pressure relief and load redistribution by custom-made insoles in diabetic patients with neuropathy and foot deformity, Clin Biomech, 2004, 19, 6, 629-638, https://doi. org/10.1016/j.clinbiomech.2004.02.010.

26. Paton, J.S., Stenhouse, E.A., Bruce, G., Zahra, D., Jones, R.B., A comparison of customised and prefabricated insoles to reduce risk factors for neuropathic diabetic foot ulceration: a participant-blinded randomised controlled trial, J Foot Ankle Res, 2012, 5, 11, WOS: 000314610300001, https://doi. org/10.1186/1757-1146-5-31.

27. Burns, J., Wegener, C., Begg, L., Vicaretti, M., Fletcher, J., Randomized trial of custom orthoses and footwear on foot pain and plantar pressure in diabetic peripheral arterial disease, Diabet Med, 2009, 26, 9, 893-899, WOS: 000269366400008, https:// doi.org/10.1111/j.1464-5491.2009.02799.x.

28. Waaijman, R., Arts, M.L.J., Haspels, R., Busch-Westbroek, T.E., Nollet, F., Bus, S.A., Pressure-reduction and preservation in custom-made footwear of patients with diabetes and a history of plantar ulceration, Diabet Med, 2012, 29, 12, 1542-1549, WOS: 000311054600019, https://doi.org/10.1111/ j.1464-5491.2012.03700.x.

29. Hellstrand Tang, U., Zugner, R., Lisovskaja, V., Karlsson, J., Hagberg, K., Tranberg, R., Comparison of plantar pressure in three types of insole given to patients with diabetes at risk of developing foot ulcers - A two-year, randomized trial, J Clin Transl Endocrinol, 2014, 1, 4, 121-132, MEDLINE: 29159093, https://doi.org/10.1016/j.jcte.2014.06.002. 
30. Bus, S.A., van Deursen, R.W.M., Kanade, R.V., Wissink, M., Manning, E.A., van Baal, J.G., Harding, K.G., Plantar pressure relief in the diabetic foot using forefoot offloading shoes, Gait Posture, 2009, 29, 4, 618-622, https:// doi.org/10.1016/j.gaitpost.2009.01.003.

31. Owings, T.M., Woerner, J.L., Frampton, J.D., Cavanagh, P.R., Botek, G., Custom therapeutic insoles based on both foot shape and plantar pressure measurement provide enhanced pressure relief, Diabetes Care, 2008, 31, 5, 839-844, WOS: 000256016300001, https:// doi.org/10.2337/dc07-2288.

32. Guldemond, N.A., Leffers, P., Schaper, N.C., Sanders, A.P., Nieman, F., Willems, P., Walenkamp, G.H.I.M., The effects of insole configurations on forefoot plantar pressure and walking convenience in diabetic patients with neuropathic feet, Clin Biomech, 2007, 22, 1, 81-87, https://doi.org/10.1016/j. clinbiomech.2006.08.004.

33. Ashry, H.R., Lavery, L.A., Murdoch, D.P., Frolich, M., Lavery, D.C., Effectiveness of diabetic insoles to reduce foot pressures, J Foot Ankle Surg, 1997, 36, 4, 268-71; discussion 328-9, MEDLINE: 9298441, https://doi.org/10.1016/ S1067-2516(97)80071-3.

34. Parker, D.J., Nuttall, G.H., Bray, N., Hugill, T., Martinez-Santos, A., Edwards, R.T., Nester, C., A randomised controlled trial and costconsequence analysis of traditional and digital foot orthoses supply chains in a National Health Service setting: application to feet at risk of diabetic plantar ulceration, J Foot Ankle Res, 2019, 12, WOS: 000455264900001, https://doi.org/10.1186/s13047-018-0311-0.

35. Bus, S.A., Waaijman, R., Arts, M., de Haart, M., Busch-Westbroek, T., van Baal, J., Nollet, F., Effect of Custom-Made Footwear on Foot Ulcer Recurrence in Diabetes A multicenter randomized controlled trial, Diabetes Care, 2013, 36, 12, 4109-4116, WOS: 000327211500065, https://doi.org/10.2337/ dc13-0996.

36. Nagel, A., Rosenbaum, D., Vacuum cushioned removable cast walkers reduce foot loading in patients with diabetes mellitus, Gait Posture, 2009, 30, 1, 1115, WOS: 000266905000003 , https://doi. org/10.1016/j.gaitpost.2009.02.007.
37. Bus, S.A., Haspels, R., Busch-Westbroek, T.E., Evaluation and Optimization of Therapeutic Footwear for Neuropathic Diabetic Foot Patients Using In-Shoe Plantar Pressure Analysis, Diabetes Care, 2011, 34, 7, 15951600, WOS: 000293261200030 , https://doi. org/10.2337/dc10-2206.

38. Viswanathan, V., Madhavan, S., Gnanasundaram, S., Gopalakrishna, G., Das, B.N., Rajasekar, S., Ramachandran, A., Effectiveness of different types of footwear insoles for the diabetic neuropathic foot - A follow-up study, Diabetes Care, 2004, 27, 2, 474-477, WOS: 000188739900029, https:// doi.org/10.2337/diacare.27.2.474.

39. Arts, M.L.J., de Haart, M., Waaijman, R., Dahmen, R., Berendsen, H., Nollet, F., Bus, S.A., Data-driven directions for effective footwear provision for the high-risk diabetic foot, Diabet Med, 2015, 32, 6, 790-797, WOS: 000354637600013, https://doi.org/10.1111/ dme.12741.

40. Lord, M., Hosein, R., Pressure Redistribution by Molded Inserts in Diabetic Footwear - A Pilot-Study, J Rehabil Res Dev, 1994, 31, 3, 214-221, WOS: A1994PE45700005.

41. Randolph, A.L., Nelson, M., Akkapeddi, S., Levin, A., Alexandrescu, R., Reliability of measurements of pressures applied on the foot during walking by a computerized insole sensor system, Arch Phys Med Rehabil, 2000, 81, 5, 573-578, WOS: 000086867800006, https://doi.org/10.1016/ S0003-9993(00)90037-6.

42. Drerup, B., Beckmann, C., Wetz, H.H., Effect of body weight on plantar peak pressure in diabetic patients, Orthopade, 2003, 32, 3, 199-206, WOS: 000182200300003, https:// doi.org/10.1007/s00132-002-0444-4.

43. Janisse, D.J., Janisse, E., Shoe modification and the use of orthoses in the treatment of foot and ankle pathology, J Am Acad Orthop Surg, 2008, 16, 3, 152-158, WOS: 000253744500006 , https://doi. org/10.5435/00124635-200803000-00006.

44. Jarl, G., Tranberg, R., An innovative sealed shoe to off-load and heal diabetic forefoot ulcers - a feasibility study, Diabet Foot Ankle, 2017, 8, 1, 1348178, MEDLINE: 28804593, https://doi.org/10.1080/200062 5X.2017.1348178. 
45. Veitenhansl, M., Hierl, F.X., Landgraf, R., Pressure reduction through various premanufactured shoe models with insoles in diabetic foot syndrome to prevent ulceration: a prospective randomised study, Diabetologia, 2003, 46, A4-A5, WOS: 000185242100007.

46. Kastenbauer, T., Sokol, G., Auinger, M., Irsigler, K., Running shoes for relief of plantar pressure in diabetic patients, Diabet Med, 1998, 15, 6, 518-522, WOS: 000073898400014, https://doi.org/10.1002/ (SICl)1096-9136(199806)15:6\%3C518::AIDDIA623\%3E3.0.CO;2-J.

47. Zequera, M., Stephan, S., Paul, J., Effectiveness of moulded insoles in reducing plantar pressure in diabetic patients, 2007 Annual International Conference of the leee Engineering in Medicine and Biology Society, Vols 1-162007, pp. 4671, https://doi. org/10.1109/IEMBS.2007.4353382.
48. Lavery, L.A., LaFontaine, J., Higgins, K.R., Lanctot, D.R., Constantinides, G., Shear-Reducing Insoles to Prevent Foot Ulceration in High-Risk Diabetic Patients, Adv Skin Wound Care, 2012, 25, 11, 519524, WOS: 000310361800007 , https://doi. org/10.1097/01.ASW.0000422625.17407.93.

49. Paton, J., Bruce, G., Jones, R., Stenhouse, E., Effectiveness of insoles used for the prevention of ulceration in the neuropathic diabetic foot: a systematic review, J Diabetes Complications, 2011, 25, 1, 5262, WOS: 000285899600009, https://doi. org/10.1016/j.jdiacomp.2009.09.002.

C 2020 by the author(s). Published by INCDTPICPI, Bucharest, RO. This is an open access article distributed under the terms and conditions of the Creative Commons Attribution license (http:// creativecommons.org/licenses/by/4.0/). 